\title{
Peptide Couplings by Reactive Extrusion: Solid-Tolerant and Free from Carcinogenic, Mutagenic and Reprotoxic Chemicals
}

\author{
Yves Yeboue, ${ }^{\dagger}$ Benjamin Gallard, ${ }^{\ddagger}$ Nicolas Le Moigne, ${ }^{\ddagger}$ Marion Jean, ${ }^{\S}$ Frédéric Lamaty, ${ }^{\dagger}$ Jean Martinez, $^{\dagger}$ \\ and Thomas-Xavier Métro* ${ }^{* \dagger}$ \\ †Institut des Biomolécules Max Mousseron (IBMM), UMR 5247, CNRS, Université de Montpellier, ENSCM, Université de \\ Montpellier, Campus Triolet, Place Eugène Bataillon, 34095 Montpellier Cedex 5, France \\ ${ }^{\ddagger}$ C2MA, IMT Mines Alès, Université de Montpellier, 6 avenue de Clavières, 30319 Alès Cedex, France \\ ${ }^{\S}$ Institut des Sciences Moléculaires de Marseille, Aix-Marseille Université, CNRS, Centrale Marseille, iSm2, 13013 Marseille, France
}

ABSTRACT: Industrial peptide synthesis is generally carried out in batches and suffers both from the production of tremendous amounts of toxic waste and the difficulty to handle solids. In this study, peptide couplings were performed at the multigram scale by using reactive extrusion in a CMRfree $(\mathrm{CMR}=$ Carcinogenic, Mutagenic or Reprotoxic), solidtolerant, fast, efficient and epimerization-free manner, opening the way for intensified and continuous industrial production of peptides.

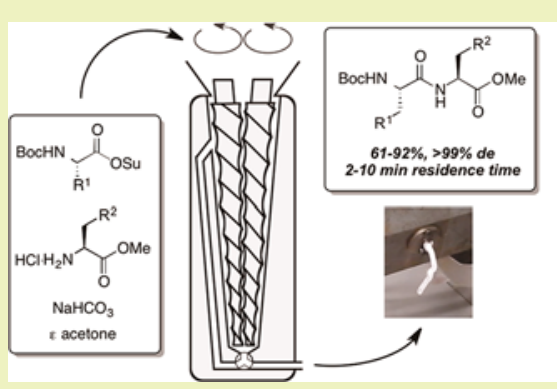

Peptide Couplings by Reactive Extrusion

CMR-free

Solid-tolerant Efficient

Fast

Versatile

Continuous

KEYWORDS: Peptide, Reactive extrusion, Continuous flow, Solid-tolerance, Innocuous reactants

\section{INTRODUCTION}

Peptides find many applications in the fields of cosmetics, pharmaceuticals and nutriments. Yet, the majority of industrial production of peptides operates either in solution or by solid phase peptide synthesis (SPPS), and suffers from the huge amounts of toxic organic solvents and reagents that are required during the synthesis and purification steps. ${ }^{1-5}$ Although being classified as CMR (carcinogenic, mutagenic or reprotoxic), polar aprotic solvents such as DMF, DCM, THF and 1,4-dioxane are regularly used (According to Regulation (EC) No. 1272/2008, DMF is classified as presenting reproductive toxicity and DCM, THF and 1,4dioxane as toxic and/or carcinogenic Category 2). Under the pressure of REACH implementation, peptide manufacturers have called for alternatives to these solvents. ${ }^{5,6}$ The development of industrial peptide production is also hampered by the conventional discontinuous batch mode of production as well as by the limitations related to the general low solubility of peptides. In practice, utilization of a solvent is not mandatory to perform peptide synthesis as long as reactants are ground and mixed together through application of mechanical forces. $^{7,8}$ Indeed, the solvent-free synthesis of various dipeptides, including the sweetener Aspartame, was described in 2009 by grinding together in a ball-mill urethane-protected $\alpha$-amino acid $N$-carboxyanhydride (UNCA), $\alpha$-amino ester salts and $\mathrm{NaHCO}_{3}{ }^{7}$ Based on this new paradigm, other solid tolerant peptide production processes by ball-milling were described, ${ }^{9-18}$ enabling to produce $4 \mathrm{~g}$ of a dipeptide for the best case. ${ }^{8}$ Yet, these ball-milling processes are limited to discontinuous batch production and further up-scaling is not straightforward, thereby preventing them from a wide dissemination among the peptide production industry. ${ }^{19}$ On the opposite, traditional solution-based continuous flow peptide production processes proved beneficial when considering scalability, ${ }^{20}$ but become seriously limited when considering highly concentrated reaction mixtures and the related appearance of solids.

In this work, we report merging the best of these two approaches by performing peptide synthesis in an extruder (Figure 1).

\section{RESULTS AND DISCUSSION}

Extruders are composed of a barrel containing one or two rotating screws enabling the efficient transport and mixing of material through compression and shearing forces. Advantageously, this type of equipment allows one to work under controlled and continuous flow conditions, while the barrel can be heated up to induce a melted phase facilitating the overall extrusion of the reaction mixture. On the contrary to classical solution-based flow chemistry, extruders enable the efficient mixing of viscous and/or solid-containing reaction mixtures. As exemplified by production at the multiton scale by the food and plastic industry, the scalability of extrusion processes is known to be devoid of major difficulties. Although identified as 


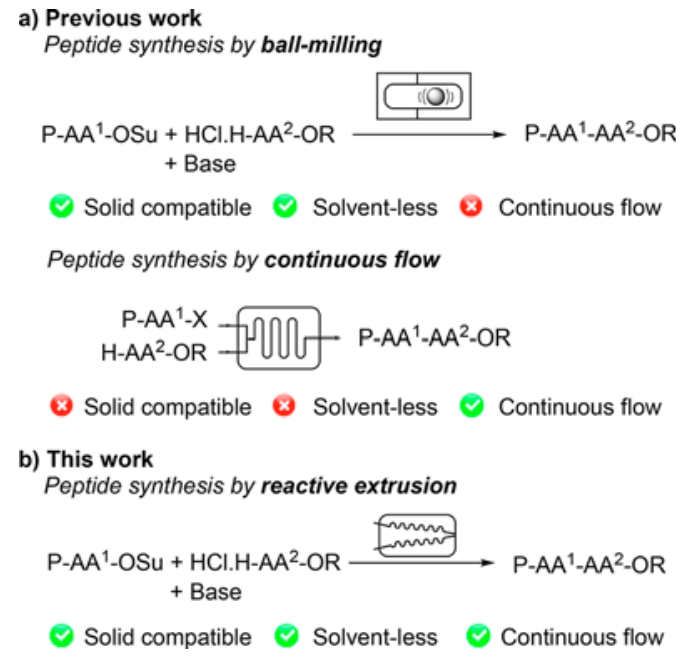

Figure 1. Advantages of peptide couplings by reactive extrusion compared to ball-milling and continuous flow strategies.

a key research area by the pharmaceutical industry, ${ }^{21}$ production of high-added-value chemicals by reactive extrusion has been scarce. ${ }^{22-31}$ First examples reported in the literature described the formation of organic cocrystals. ${ }^{22-25}$ Later, reactive extrusion was applied to the synthesis of metalorganic frameworks (MOF), ${ }^{26}$ deep eutectic solvents (DES), ${ }^{27}$ covalent-organic frameworks (COF), ${ }^{28} \alpha, \beta$-unsaturated carbonyls and imines, ${ }^{29,30}$ and benzilic alcohols obtained by reduction of aromatic aldehydes with $\mathrm{NaBH}_{4}{ }^{31}$ Recently, the possibility to synthesize homo-oligo-peptides by enzymecatalyzed polymerization of $\alpha$-L-amino acid ester hydrochlorides by reactive extrusion was described. ${ }^{32}$ Yet, such a method does not allow any possibility to finely control the introduction of various amino acids in a single peptide sequence, which is crucial for the vast majority of peptide of interest. Considering the application of reactive extrusion to the synthesis of peptides, we decided to study the capacity of a corotating twin-screw extruder (MC15 microcompounder, Xplore) to produce the dipeptide Boc-Trp-Gly-OMe by reacting Boc-Trp-OSu with $\mathrm{HCl} \cdot \mathrm{H}-\mathrm{Gly}-\mathrm{OMe}$ and $\mathrm{NaHCO}_{3}$ in the absence of solvent. Yet, the reaction mixture could not be extruded due to the absence of a melted phase preventing proper rotation of the screws. Heating the extrusion chamber at $100{ }^{\circ} \mathrm{C}$ did not solve the problem. In order to improve the flowing of the reaction mixture within the extruder chamber, various liquid additives were screened, leading to the identification of acetone as the best liquid additive (see Supporting Information for details of the screening). Then, Boc-Trp-OSu (6.3 g, 1.0 equiv), $\mathrm{HCl} \cdot \mathrm{H}-\mathrm{Gly}-\mathrm{OMe}(2.2 \mathrm{~g}, 1.1$ equiv) and $\mathrm{NaHCO}_{3}(1.6 \mathrm{~g}, 1.2$ equiv) were poured together with acetone $(1.5 \mathrm{~mL}, \eta=0.15 \mathrm{~mL} / \mathrm{g} ; \eta$ is defined as the ratio between the volume of liquid (in $\mathrm{mL}$ ) divided by the total mass of solids (in gram)) into the extruder operated at $40{ }^{\circ} \mathrm{C}$, while the screw speed was fixed at $50 \mathrm{rpm}$. By using the recirculation pipe of the extruder, the reaction mixture could be mixed for 5 min before being recovered as a dense paste containing solid particles. This paste was quenched and analyzed by HPLC, indicating a conversion of $73 \%$ (Table 1 , entry 1 ). Of note, only $1.5 \mathrm{~mL}$ of acetone was introduced in the extruder to process a total mass of $10 \mathrm{~g}$ of solid reactants, which is far below the quantities that are necessary to obtain a suspension or a solution that could be properly mixed by
Table 1. Influence of Temperature, Mixing Time and Screw Speed on the Production of Boc-Trp-Gly-OMe

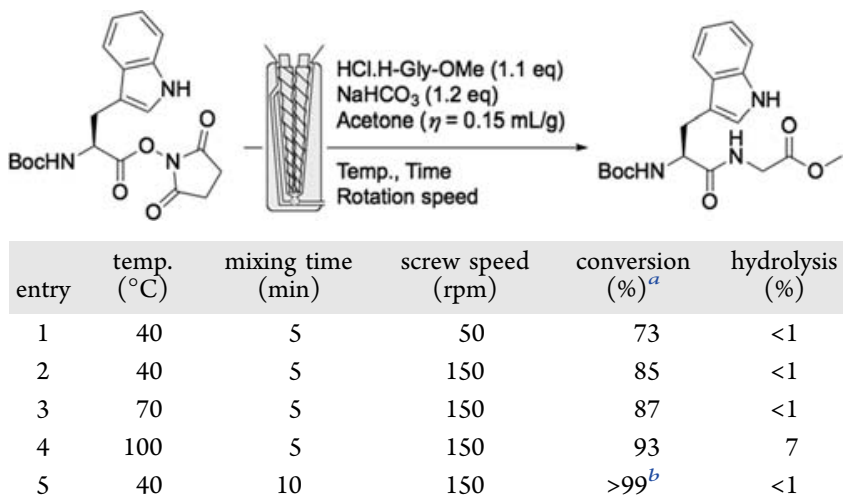

${ }^{a}$ Determined by HPLC. ${ }^{b}$ Boc-Trp-Gly-OMe was produced in $85 \%$ yield with $>99 \%$ enantiomeric excess.

classical agitation techniques used in solution-based syntheses. Increasing the screw speed to $150 \mathrm{rpm}$ and the temperature up to $70{ }^{\circ} \mathrm{C}$ had a positive effect on the conversion (Table 1 , entries 2 and 3). Conversion reached 93\% when the barrel was heated at $100{ }^{\circ} \mathrm{C}$, yet leading to partial hydrolysis of Boc-TrpOSu into Boc-Trp-OH (Table 1, entry 4). When the reaction mixture was recirculated for $10 \mathrm{~min}$ at $40{ }^{\circ} \mathrm{C}$ and $150 \mathrm{rpm}$, complete conversion of Boc-Trp-OSu was obtained with no traces of Boc-Trp-OH resulting from Boc-Trp-OSu hydrolysis. After classical workup of the extrudate (EtOAc solubilization and aqueous washings), Boc-Trp-Gly-OMe was produced in $85 \%$ yield with complete retention of the enantiomeric excess (>99\% ee; Table 1, entry 5).

These optimized reaction conditions were then applied to the synthesis of Boc-Trp-Phe-OMe that could be isolated in $61 \%$ yield and $>99 \%$ diastereomeric excess (Table 2 , entry 1 ). To our delight, Boc-Asp(OBzl)-OSu was even more reactive than Boc-Trp-OSu as Boc-Asp(OBzl)-Phe-OMe could be obtained without the need to recirculate the reaction mixture in the extruder. The $1.5 \mathrm{~min}$ residence time in the extrusion barrel was sufficient to get full conversion of Boc-Asp (OBzl)OSu, leading to Boc-Asp(OBzl)-Phe-OMe in $92 \%$ yield and $>99 \%$ de (Table 2, entry 2). After Boc removal by solvent-free gaseous $\mathrm{HCl}$ treatment, $\mathrm{HCl} \cdot \mathrm{H}-\mathrm{Trp}-\mathrm{Gly}-\mathrm{OMe}$ and $\mathrm{HCl} \cdot \mathrm{H}-$ Trp-Phe-OMe were reacted with Boc-Asp(OBzl)-OSu in the extruder. Corresponding Boc-Asp(OBzl)-Trp-Gly-OMe and Boc-Asp(OBzl)-Trp-Phe-OMe tripeptides were produced in $86 \%$ and $89 \%$ yield and excellent purity (96\% and $94 \%$ respectively; Table 2, entries 3 and 4 ).

The efficiency of the reactive extrusion process was then evaluated by calculating the space-time yields (STY) and compared with syntheses performed by ball-milling and in solution under classical magnetic agitation. STY is defined as the amount of final product per volume of the reactor per time of reaction (expressed in $\mathrm{g} \mathrm{cm}^{-3} \mathrm{day}^{-1}$ ) and therefore is a very useful tool to assess process intensification. When the synthesis was performed by ball-milling, $\mathrm{NaHCO}_{3}$ was used as the base and acetone as the liquid grinding assistant, whereas $\mathrm{Et}_{3} \mathrm{~N}$ and DMF were chosen as the best candidates for the syntheses in solution. Of note, to ensure rigorous comparison with the other processes, syntheses in solution were realized by using the minimal amount of DMF enabling proper agitation of the reaction mixture. For all the three dipeptides evaluated, the STY of the reactive extrusion processes were much higher than 
Table 2. Synthesis of Various Di- and Tripeptides by Reactive Extrusion

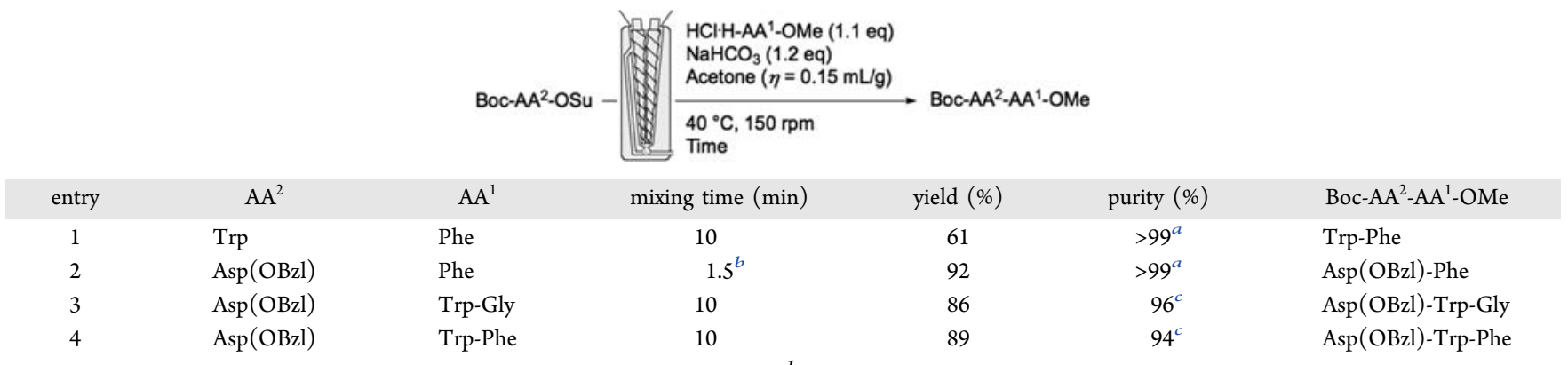

${ }^{a}>99 \%$ de determined by HPLC. See Supporting Information for details. ${ }^{b}$ Reaction mixture was extruded without recirculation. Residence time of 1.5 min. ${ }^{c}$ Purity determined by HPLC.

Table 3. Space Time Yield (STY) of Syntheses Performed in the Extruder, in the Ball-Mill and in Solution

\begin{tabular}{|c|c|c|c|c|}
\hline \multirow[b]{2}{*}{ entry } & \multirow[b]{2}{*}{$\mathrm{BocAA}^{2} \mathrm{AA}^{1} \mathrm{OMe}$} & \multicolumn{3}{|c|}{$\mathrm{STY}^{a}$} \\
\hline & & extruder & ball-mill & solution $^{c}$ \\
\hline 1 & Trp-Gly & 48.0 & 2.6 & 1.8 \\
\hline 2 & Trp-Phe & 37.0 & 2.1 & 1.1 \\
\hline 3 & Asp(OBzl)-Phe & 471.2 & 2.2 & $4.9(0.2)^{d}$ \\
\hline
\end{tabular}

${ }^{a}$ STY expressed in $\mathrm{g} \mathrm{cm}^{-3} \mathrm{day}^{-1}$. See Supporting Information for details of the calculations. ${ }^{b}$ Calculation based on a continuous flow mode of production. ${ }^{c}$ Reaction performed with $\mathrm{Et}_{3} \mathrm{~N}$ as the base and DMF as the solvent. ${ }^{d}$ Performed with $\mathrm{NaHCO}_{3}$ as the base and acetone as the solvent.

for ball-milling and solution syntheses, by 2 orders of magnitude for the best case (Table 3, entry 3). Of note, the STY obtained by reactive extrusion were also much higher than the ones calculated from literature data (see Supporting Information for details). In addition to be much more productive, reactive extrusion enables to work with much safer chemicals $\left(\mathrm{NaHCO}_{3}\right.$ and acetone) than classical solutionbased processes (using $\mathrm{Et}_{3} \mathrm{~N}$ and DMF).

Although we did not demonstrate the efficiency of this strategy on the synthesis of longer peptides that are already accessible by SPPS, the potential impact of this reactive extrusion process was illustrated by the production of the industrially relevant dipeptide Aspartame. Indeed, this famous sweetener could be obtained by hydrogenation of BocAsp(OBzl)-Phe-OMe to remove the benzyl group followed by deprotection of the Boc group under solvent-free gaseous $\mathrm{HCl}$ conditions (Scheme 1). Aspartame was finally obtained by precipitation at the isoelectric point ( $\mathrm{pH}$ 5.0). Overall, Aspartame was isolated in three steps in $81 \%$ yield.

\section{CONCLUSION}

In conclusion, we have shown that reactive extrusion enables to produce di- and tripeptides in high yields and high stereoisomeric excesses. Reaction times were very short while reaction conditions were free from CMR chemicals. The highly problematic solvents and bases used in classical reaction conditions (such as DMF and $\mathrm{Et}_{3} \mathrm{~N}$ ) were replaced with much preferable ones (acetone, $\mathrm{NaHCO}_{3}, \mathrm{EtOAc}$ ). Unlike conventional synthesis approaches (solvent-based continuous flow, liquid phase or SPPS), the presence of solids in the reaction mixtures was not an obstacle to the success of the syntheses. When compared to synthesis in solution, this strategy enabled to tremendously increase the space time yields $\left(10^{2}\right.$ times in the best cases). The possibility to work under continuous
Scheme 1. Application to the Synthesis of Aspartame

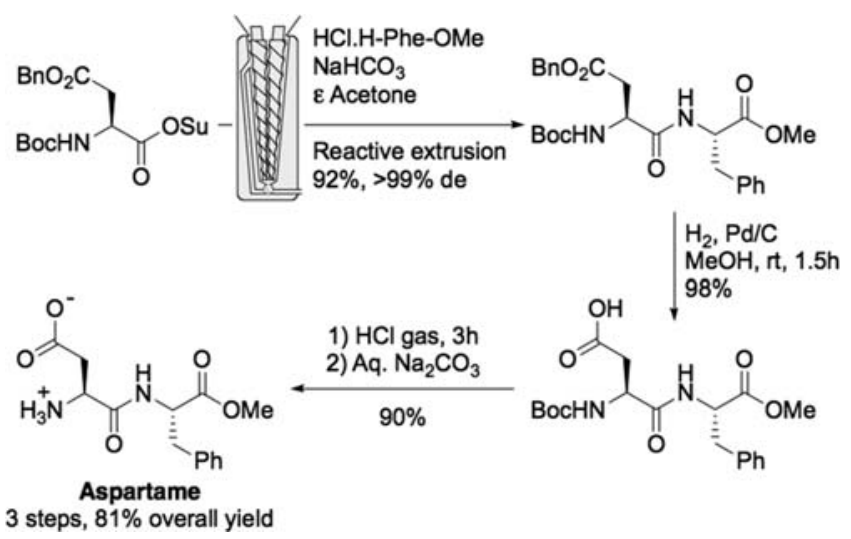

conditions was also demonstrated, paving the way to intensified and continuous industrial production of peptides. Finally, potential industrial applications have been demonstrated by the efficient production of a precursor of the famous sweetener Aspartame. Further applications of this reactive extrusion approach are currently under way in our laboratories, and will be reported in due course. 
(1) Bray, B. L. Large-scale manufacture of peptide therapeutics by chemical synthesis. Nat. Rev. Drug Discovery 2003, 2, 587-593.

(2) Thayer, A. M. Making Peptides At Large Scale. Chem. Eng. News 2011, 89, 21-25.

(3) Mergler, M.; Loidl, G.; Diekmann, M.; Dick, F. Bachem insights into peptide chemistry achievements by the world's leading independent manufacturer of peptides. Chimia 2013, 67, 874-880.

(4) Werbitzky, O.; Giraud, M. Manufacturing of venom-derived therapeutic peptides. RSC Drug Discovery Series 2015, 42, 290-305.

(5) Patel, P. Executive reveals how Amgen shifted to greener chemistry. Chem. Eng. News 2017, 95, 27-28.

(6) Constable, D. J. C.; Dunn, P. J.; Hayler, J. D.; Humphrey, G. R.; Leazer, J. L., Jr.; Linderman, R. J.; Lorenz, K.; Manley, J.; Pearlman, B. A.; Wells, A.; Zaks, A.; Zhang, T. Y. Key green chemistry research areas-a perspective from pharmaceutical manufacturers. Green Chem. 2007, 9, 411-420.

(7) Declerck, V.; Nun, P.; Martinez, J.; Lamaty, F. Solvent-Free Synthesis of Peptides. Angew. Chem., Int. Ed. 2009, 48, 9318-9321.

(8) Métro, T.-X.; Colacino, E.; Martinez, J.; Lamaty, F. In Ball Milling Towards Green Synthesis: Applications, Projects, Challenges; Ranu, B., Ed.; The Royal Society of Chemistry, 2015; pp 114-150.

(9) Hernández, J. G.; Juaristi, E. Green Synthesis of $\alpha, \beta$ - and $\beta, \beta$ Dipeptides under Solvent-Free Conditions. J. Org. Chem. 2010, 75, 7107-7111

(10) Strukil, V.; Bartolec, B.; Portada, T.; Bilović, I.; Halasz, I.; Margetic, D. One-pot mechanosynthesis of aromatic amides and dipeptides from carboxylic acids and amines. Chem. Commun. 2012, $48,12100-12102$.

(11) Duangkamol, C.; Jaita, S.; Wangngae, S.; Phakhodee, W.; Pattarawarapan, M. An efficient mechanochemical synthesis of amides and dipeptides using 2,4,6-trichloro-1,3,5-triazine and PPh3. RSC Adv. 2015, 5, 52624-52628

(12) Porte, V.; Thioloy, M.; Pigoux, T.; Métro, T.-X.; Martinez, J. Lamaty, F. Peptide Mechanosynthesis by Direct Coupling of NProtected $\alpha$-Amino Acids with Amino Esters. Eur. J. Org. Chem. 2016, 2016, 3505-3508.

(13) Landeros, J. M.; Juaristi, E. Mechanochemical synthesis of dipeptides using $\mathrm{Mg}-\mathrm{Al}$ hydrotalcite as activating agent under solventfree reaction conditions. Eur. J. Org. Chem. 2017, 2017, 687-694.

(14) Gonnet, L.; Tintillier, T.; Venturini, N.; Konnert, L.; Hernandez, J.-F.; Lamaty, F.; Laconde, G.; Martinez, J.; Colacino, E. N-Acyl Benzotriazole Derivatives for the Synthesis of Dipeptides and Tripeptides and Peptide Biotinylation by Mechanochemistry. ACS Sustainable Chem. Eng. 2017, 5, 2936-2941.

(15) Hernández, J. G.; Ardila-Fierro, K. J.; Crawford, D.; James, S.; Bolm, C. Mechanoenzymatic peptide and amide bond formation. Green Chem. 2017, 19, 2620-2625.

(16) Maurin, O.; Verdié, P.; Subra, G.; Lamaty, F.; Martinez, J. Métro, T.-X. Peptide synthesis: ball-milling, in solution, or on solid support, what is the best strategy? Beilstein J. Org. Chem. 2017, 13, 2087-2093.

(17) Pétry, N.; Benakki, H.; Clot, E.; Retailleau, P.; Guenoun, F.; Asserar, F.; Sekkat, C.; Métro, T.-X.; Martinez, J.; Lamaty, F. A mechanochemical approach to access the proline-proline diketopiperazine framework. Beilstein J. Org. Chem. 2017, 13, 2169-2178.

(18) Bonnamour, J.; Métro, T.-X.; Martinez, J.; Lamaty, F. Environmentally benign peptide synthesis using liquid-assisted ballmilling: application to the synthesis of Leu-enkephalin. Green Chem. 2013, 15, 1116-1120.

(19) James, S. L.; Adams, C. J.; Bolm, C.; Braga, D.; Collier, P.; Friščić, T.; Grepioni, F.; Harris, K. D. M.; Hyett, G.; Jones, W.; Krebs, A.; Mack, J.; Maini, L.; Orpen, A. G.; Parkin, I. P.; Shearouse, W. C.;
Steed, J. W.; Waddell, D. C. Mechanochemistry: opportunities for new and cleaner synthesis. Chem. Soc. Rev. 2012, 41, 413-447.

(20) Gordon, C. P. The renascence of continuous-flow peptide synthesis - an abridged account of solid and solution-based approaches. Org. Biomol. Chem. 2018, 16, 180-196.

(21) Jiménez-González, C.; Poechlauer, P.; Broxterman, Q. B.; Yang, B.-S.; am Ende, D.; Baird, J.; Bertsch, C.; Hannah, R. E.; Dell'Orco, P.; Noorman, H.; Yee, S.; Reintjens, R.; Wells, A.; Massonneau, V.; Manley, J. Key Green Engineering Research Areas for Sustainable Manufacturing: A Perspective from Pharmaceutical and Fine Chemicals Manufacturers. Org. Process Res. Dev. 2011, 15, 900-911.

(22) Dhumal, R. S.; Kelly, A. L.; York, P.; Coates, P. D.; Paradkar, A. Cocrystalization and Simultaneous Agglomeration Using Hot Melt Extrusion. Pharm. Res. 2010, 27, 2725-2733.

(23) Medina, C.; Daurio, D.; Nagapudi, K.; Alvarez-Núñez, F. Manufacture of pharmaceutical co-crystals using twin screw extrusion: A solvent-less and scalable process. J. Pharm. Sci. 2010, 99, 16931696.

(24) Daurio, D.; Medina, C.; Saw, R.; Nagapudi, K.; Alvarez-Núñez, F. Application of Twin Screw Extrusion in the Manufacture of Cocrystals, Part I: Four Case Studies. Pharmaceutics 2011, 3, 582600.

(25) Daurio, D.; Nagapudi, K.; Li, L.; Quan, P.; Nunez, F.-A. Application of twin screw extrusion to the manufacture of cocrystals: scale-up of AMG 517-sorbic acid cocrystal production. Faraday Discuss. 2014, 170, 235-249.

(26) Crawford, D.; Casaban, J.; Haydon, R.; Giri, N.; McNally, T.; James, S. L. Synthesis by extrusion: continuous, large-scale preparation of MOFs using little or no solvent. Chem. Sci. 2015, 6, $1645-1649$.

(27) Crawford, D. E.; Wright, L. A.; James, S. L.; Abbott, A. P. Efficient continuous synthesis of high purity deep eutectic solvents by twin screw extrusion. Chem. Commun. 2016, 52, 4215-4218.

(28) Karak, S.; Kandambeth, S.; Biswal, B. P.; Sasmal, H. S.; Kumar, S.; Pachfule, P.; Banerjee, R. Constructing Ultraporous Covalent Organic Frameworks in Seconds via an Organic Terracotta Process. J. Am. Chem. Soc. 2017, 139, 1856-1862.

(29) Crawford, D. E.; Miskimmin, C. K. G.; Albadarin, A. B.; Walker, G.; James, S. L. Organic synthesis by Twin Screw Extrusion (TSE): continuous, scalable and solvent-free. Green Chem. 2017, 19, $1507-1518$.

(30) Crawford, D.; Miskimmin, C.; Cahir, J.; James, S. Continuous multi-step synthesis by extrusion - telescoping solvent-free reactions for greater efficiency. Chem. Commun. 2017, 53, 13067-13070.

(31) Isoni, V.; Mendoza, K.; Lim, E.; Teoh, S. K. Screwing NaBH4 through a Barrel without a Bang: A Kneaded Alternative to Fed-Batch Carbonyl Reductions. Org. Process Res. Dev. 2017, 21, 992-1002.

(32) Ardila-Fierro, K. J.; Crawford, D.; Korner, A.; James, S.; Bolm, C.; Hernandez, J. G. Papain-catalysed mechanochemical synthesis of oligopeptides by milling and twin-screw extrusion; application in the Julia-Colonna enantioselective epoxidation. Green Chem. 2018, 20, $1262-1269$. 